\title{
Sunlight transmitted by colored shade nets on photosynthesis and yield of cucumber
}

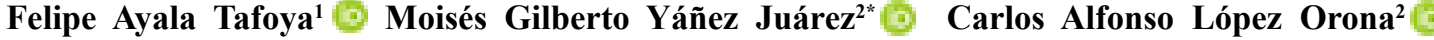 \\ Raymundo Medina López ${ }^{2}$ Teresa de Jesús Velázquez Alcaraz ${ }^{1}$ T Tomás Díaz Valdés ${ }^{3}$
}

${ }^{1}$ Departamento de Horticultura, Facultad de Agronomía, Universidad Autónoma de Sinaloa (UAS), Culiacán, Sinaloa, México.

${ }^{2}$ Departamento de Protección Vegetal, Facultad de Agronomía, Universidad Autónoma de Sinaloa (UAS), 80000, Culiacán, Sinaloa, México. E-mail: moisesyj@uas.edu.mx. "Corresponding author.

${ }^{3}$ Departamento de Suelos y Agua, Facultad de Agronomía, Universidad Autónoma de Sinaloa (UAS), Culiacán, Sinaloa, México.

\begin{abstract}
Black shading nets are widely used in the protected cultivation of vegetables as a technique for controlling light and temperature, while the colored shading nets, with special optical properties to improve the use of solar radiation, appeared recently in the agricultural plastics market. Light quality transmitted by gray, aluminized, pearl, blue, red and black (control) nets with $30 \%$ shade was evaluated, as well as its effects on photosynthetic properties and fruits production of cucumber plants. Treatments (shade nets) were established under a randomized complete block design with four repetitions. The red net transmitted 23.7 and $40.3 \%$ more photosynthetic photon flux density (400 to $700 \mathrm{~nm}$ ) and red light (600 to $700 \mathrm{~nm}$ ) and the blue net transmitted 36\% more blue light (400 to 500nm) in comparison with the respective transmissions of black net. All nets increased the photosynthetic responses: transpiration, stomatal conductance and $\mathrm{CO}_{2}$ assimilation, observed in plants grown under black net. Leaf greenness (41.6 SPAD units) and foliar area $\left(90 \mathrm{dm}^{2}\right)$ increased 22.8 and $38.9 \%$ with the red net, while the dry weight of leaf (52.5g) increased $21.9 \%$ with pearl net. Pearl, red, aluminized and blue nets showed to be viable alternatives because the production of fruit increased in 71, 48, 46 and 46\%, respectively, in comparison with the conventional black net (52t ha ${ }^{-1}$ ). Key words: Cucumis sativus L., light transmission, photosynthetic responses, leaf growth, fruit production.
\end{abstract}

Luz solar transmitida por malhas coloridas sobre fotossíntese e rendimento de pepino

RESUMO: As malhas de sombreamento preto são amplamente utilizadas no cultivo protegido de hortaliças como uma técnica para controlar a luz e a temperatura; enquanto as malhas de sombreamento coloridas, com propriedades ópticas especiais para melhorar o uso da radiação solar, apareceram recentemente no mercado de plásticos agrícolas. A qualidade de luz transmitida por malhas cinza, aluminizada, pérola, azul, vermelha e preta (controle) com 30\% de sombreamento foi avaliada, assim como seus efeitos nas propriedades fotossintéticas e na produção de frutos de plantas de pepino. Os tratamentos (malhas de sombreamento) foram estabelecidos sob o desenho de blocos completos casualizados, com quatro repetições. A malha vermelha transmitiu 23,7 e 40,3\% mais densidade de fluxo de fótons fotossintéticos (400 a 700nm) e luz vermelha (600 a 700nm) e a malha azul transmitiu 36\% mais luz azul (400 a 500nm) em comparação com as respectivas transmissões de malha preta. Todas as malhas aumentaram as respostas fotossintéticas: transpiração, condutância estomática e assimilação de $\mathrm{CO}_{2}$, observadas em plantas cultivadas sob malha preta. O verde da folha (41,6 unidades SPAD) e a área foliar (90dm²) aumentaram 22,8 e 38,9\% com a malha vermelha, enquanto o peso seco da folha $(52,5 \mathrm{~g})$ aumentou $21,9 \%$ com a malha pérola. As malhas pérola, vermelha, aluminizada e azul mostraram-se como alternativas viáveis, pois a produção de frutos aumentou em 71, 48, 46 e 46\%, respectivamente, em comparação à malha convencional preta $\left(52 t h a^{-1}\right)$.

Palavras-chave: Cucumis sativus L., transmissão de luz, respostas fotosintéticas, crescimento foliar, produção de frutos.

\section{INTRODUCTION}

Cucumber (Cucumis sativus L.) is cultivated worldwide for several purposes: fresh consumption, pickle and cosmetics industries, mainly. In 2014 were harvested 2.18 million hectares and 74.98 million tons of fruit produced (FAO, 2017).

Greenhouse represents an option to increase cucumber production, by promoting an environment that improves the growth and development of plants (ORTIZ et al., 2009; YANG et al., 2012). However, building a greenhouse means a large investment that needs to be carefully considered. For this reason, it should be structural designs that adapt to the different needs of each crop and available resources. An economical alternative is the net house or shade net, which protects horticultural plants (leaf and fruit) from strong direct sun radiation, obtaining more vigorous plants, with higher yields and fruits of better quality than in the open field (GRUDA, 2005; AYALA-TAFOYA et al., 2011). 
Shading nets made of different materials, such as polyethylene, polypropylene and polyester or acrylic derivatives, have different rates of transmission, absorption and reflection of light and air porosity (TEITEL, 2007; AL-HELAL \& ABDEL-GHANY, 2010). Most agricultural nets used for these purpose are black and little or nothing photoselective, that is, reduce both the transmission of photosynthetically active radiation (PAR) such as near infrared (AYALA-TAFOYA et al., 2011). Horticulturists to reduce solar radiation and temperature ordinarily use such nets (LEGARREA et al., 2010; MILLER et al., 2015). Moderate shading (30-50\%) protect fruits from sunburns, reduce water use and resulted in high yields of good quality; however, more intensive shading reduce leaf photosynthesis and adversely affect productivity (SHAHAK et al., 2008; ZHU et al., 2012; DÍAZ-PÉREZ, 2013).

Plastic nets with special optical properties recently developed represent a new approach to improve the use of solar radiation in agricultural crops (GANELEVIN, 2008). Are colored shade nets, each of which specifically modifies the transmitted light spectrum in the ultraviolet, visible and far red regions, enriching the relative content of scattered light and affects its thermal components (infrared region), in function of the chromatic additives of plastic, scattering elements and weaving design (SHAHAK et al., 2004). Thus, black, grey and white nets have effect of reduction of light quantity (neutral shade), while red, blue, yellow and pearl nets have effect of changes in red and blue light composition (photo-selective shade) (COSTA et al., 2010; AYALA-TAFOYA et al., 2011; LOBOS et al., 2012; OLIVEIRA et al., 2016). In addition, pearl, white, red, blue and yellow nets increase scattered light ratio at luminous environment of cultivated plants (ORENSHAMIR et al., 2001; SHAHAK et al., 2004, 2008; ILIĆ \& FALLIK, 2017).

The application of photo-selective netting technology is gaining popularity around the world, especially in Mediterranean countries (BASILE et al., 2008; FALLIK et al., 2009; GOREN et al., 2011; BASTÍAS et al., 2012; KONG et al., 2013; KITTA et al., 2014), but also in other countries such as Serbia (MILENKOVIĆ et al., 2012; ILIĆ et al., 2015), Hungary (OMBÓDI et al., 2015), South Africa (SELAHLE et al., 2014; MASHABELA et al., 2015), Brazil (SANTANA et al., 2012; OLIVEIRA et al., 2016), and Mexico (AYALA-TAFOYA et al., 2011; MARTÍNEZ-GUTIÉRREZ et al., 2016).

Light transmission through these cover materials promotes the differential stimulation of some physiological responses regulated by light, such as photosynthesis, as a function of photosynthetic photon flux density (PPFD) and leaf content of a and b chlorophylls (ILIĆ et al., 2015; MARTÍNEZGUTIÉRREZ et al., 2016; BUTHELEZI et al., 2016; ILIĆ \& FALLIK, 2017). According to the literature, photo-selective shading nets changed plant growth and leaf anatomy (BRANT et al., 2009; BASTÍAS \& CORELLI-GRAPPADELLI, 2012; OLIVEIRA et al., 2016; MARTÍNEZ-GUTIÉRREZ et al., 2016), and incremented fruits yield and quality (BASTÍAS et al., 2012; KONG et al., 2013; TINYANE et al., 2013; MASHABELA et al., 2015; ILIĆ et al., 2015, 2017) of different cultivated vegetables, but about cucumber there is not information.

Research was carried out for knowing the transmission of photosynthetic radiation of six colored shade nets, its effects on the photosynthetic properties, leaf growth of plants and fruits yield, which can lead to replacement of the black shade net and increase the competitiveness of the cucumber producer under net house conditions.

\section{MATERIALS AND METHODS}

The research was carry out during the autumn-winter horticultural stage of Sinaloa, Mexico, in a net house (Casa sombra, ACEA, Mexico) located at coordinates $24^{\circ} 48^{\prime} 30^{\prime \prime} \mathrm{N}$ and $107^{\circ} 24^{\prime} 30^{\prime \prime} \mathrm{W}$, and $38.5 \mathrm{~m}$ of altitude. Structural characteristics of the net house are; metallic structure of $4.55 \mathrm{~m}$ height, gable roof, oriented north to south, with $80 \mathrm{~m}$ long and $40 \mathrm{~m}$ wide for a total area of $3200 \mathrm{~m}^{2}$. The roofing is a high-density polyethylene (HDPE) woven monofilament net with $16 \times 10$ crystalline threads per $\mathrm{cm}^{2}$ (Anti-aphid net, Fibras Plasticas, Mexico) of 25\% shade, and HDPE woven monofilament net with 20 crystalline threads x 10 black threads per $\mathrm{cm}^{2}$ (Antithrips bicolor net, Fibras Plasticas, Mexico) with 50\% shade in walls.

After tilling the soil, culture beds were formed distanced $1.8 \mathrm{~m}$ and mulched with coextruded plastic white/black of $25 \mu \mathrm{m}$ of thickness. Meanwhile, cucumber seeds (Modan F1, Rijk Zwaan, Mexico), parthenocarpic slicer type, were sown in 200-well polystyrene trays filled with a mixture of peat (Brown 025W, Kekkila, Finland) and perlite (Multiperl $^{\circledR}$ horticulture, Mexico) in a ratio of 75:25 (v/v). Seedlings were grown in a greenhouse (Baticenital, ACEA, Mexico), as conventionally do it horticulturalists of the region, and were transplanted to the net house when seedlings had two true leaves, with a density of 2.2 plants $/ \mathrm{m}^{2}$. During 125-day culture cycle were applied 
$225,75,296,178$ and $22 \mathrm{~kg}$ of nitrogen, phosphorus, potassium, calcium and magnesium per hectare, respectively, by fertigation. The cultivation cycle was concluded when the plants reached the height of the horizontal tutors of the net house $(3.5 \mathrm{~m})$, and then apical shoot of plants were eliminated.

Treatments were six plastic nets: gray, pearl, blue, and red $\left(\mathrm{ChromatiNet}^{\mathbb{R}}\right)$, an aluminized net (Aluminet ' $\mathrm{O}$ '), and a black net as a control (Polysack Industries, Israel). All nets of raschel type, manufactured with mono-directional HDPE strips, stabilizers against ultraviolet radiation, and hole size $6 \times 8 \mathrm{~mm}$ for $30 \%$ shade. Treatments (nets) were established under a randomized complete block design, with four replicates, using as experimental plot, four culture beds of $10 \mathrm{~m}$ long $\left(72 \mathrm{~m}^{2}\right)$, and as useful plot the two central beds, leaving one culture bed $(1.8 \mathrm{~m})$ on each side and a band of equal length at each end to avoid the edge effect. In addition, each plot was separated from the others by $7.5 \mathrm{~m}$ of area without shade net, to avoid the influence of scattered light within adjacent color nets. The shade nets were placed before transplant, $0.5 \mathrm{~m}$ above the horizontal tutors of the net house.

Spectral photon flux measurements, in the range from 350 to $1050 \mathrm{~nm}$ at $1 \mathrm{~nm}$ intervals were carried out by means of a portable spectro radiometer (Field SpecPro ${ }^{\circledR}$ VNIR, ASD, USA) which was equipped with a remote cosine receptor ( $2 \pi$ steradian field of view) located at $50 \mathrm{~cm}$ above the ground. Spectral data were expressed as solar photon flux distribution (SPFD) in quantum unit $\left(\mu \mathrm{mol} \mathrm{m} \mathrm{m}^{-2} \mathrm{~s}^{-1} \mathrm{~nm}^{-1}\right)$. All measurements were made under clear sky conditions between 11:00 to 13:00h (local time) during months of the experimental period (Oct-Feb), at an interval of $3 \mathrm{~min}$, alternately in the open air, inside of shade house and in the middle of each colored shade net. From the SPFD measured in the open air and inside the net house, integrals of solar photon flux ( $\mu \mathrm{mol} \mathrm{m} \mathrm{m}^{-2} \mathrm{~s}^{-1}$ ) in the PAR wave band from 400 to $700 \mathrm{~nm}$ (PPFD), the blue waveband from 400 to $500 \mathrm{~nm}$ (blue light) and the red waveband from 600 to $700 \mathrm{~nm}$ (red light) were calculated.

Outside net house and in the middle of each colored shade net was installed a thermo-hygrometer/ data logger (DT171, CEM, Colombia) programmed to record temperature and relative humidity of the air every 30 minutes.

For the measurements corresponding to gas exchange: transpiration rate $\left(E, \mathrm{mmol} \mathrm{m}^{-2}\right.$ $\left.\mathrm{s}^{-1}\right)$, stomatal conductance $\left(g s, \mathrm{mmol} \mathrm{m} \mathrm{m}^{-2} \mathrm{~s}^{-1}\right)$ and photosynthetic $\mathrm{CO}_{2}$ assimilation rate $\left(A, \mu \mathrm{mol} \mathrm{m} \mathrm{m}^{-2}\right.$ $\mathrm{s}^{-1}$ ) a portable photosynthesis system (LCpro+, $\mathrm{ADC}$ BioScientific, UK) was used. Measurements were made on 16 fully expanded sheets. These variables were measured monthly (30, 60 and 90 days after transplant) under environmental conditions of clear sky, between 9:00 and 12:00h (local time), in plants located in the central area of each shade net.

Using sixteen cucumber plants per treatment leaf greenness were measured (30, 60 and 90 days after transplant) with a chlorophyll meter (SPAD-502Plus, Konica Minolta, Japan), leaf area with a portable leaf area meter (LI-3000A, LI-COR Inc., USA), and leaf dry weight using a precision scale (CP622, Sartorius, Germany) after oven drying (FE-292, Felisa, Mexico) to $70^{\circ} \mathrm{C}$ until constant dry weight. Fruit growth was evaluated by measuring the length and diameter of 16 fruits, every three days until its harvest. The harvest carried out three times a week, recording the number, size and weight of fruits.

The results obtained in each study variable were submitted to analysis of variance and Duncan's multiple range test $(\mathrm{P} \leq 0.05)$ for comparison of means, through STATISTICA version7 (STATSOFT, 2004).

\section{RESULTS AND DISCUSSION}

The average SPFD curves, as well as air temperature and relative humidity obtained outside and inside of the net house, and under colored shade nets, during the experimental period are shown in figure 1. Blue, red and pearl nets were those that most altered the spectrum or quality of light. Blue net transmitted more light in the blue-green region (400 to $570 \mathrm{~nm}$ ) and increased the infrared radiation flux from 730nm onwards, red net transmitted the highest photon flux from 590nm onwards; while the pearl net differed from the aluminized and gray nets increasing its transmission from $650 \mathrm{~nm}$. However, the nets did not affect the air temperature and the relative humidity was lower under the black net.

The greatest PPFD and red light occurred under the red net, which exceeded in 23.7 and $40.3 \%$ to the respective fluxes transmitted by the black net (Table 1). Meanwhile, the highest blue light transmission obtained with the blue net was $36 \%$ higher than that recorded with the black net. These results showed the ability of the black net to block the incident radiation and explain its wide use as shading net, while revealing the photo-selective transmission/ shading of the colored nets. OREN-SHAMIR et al. (2001), SHAHAK et al. (2004) and AYALA-TAFOYA et al. (2011) also indicated similar changes in quantity and quality of light because of color and design of nets, after its evaluation in cultivation of ornamental plants (Pittosporum variegatum), fruits (Vitis vinifera, 


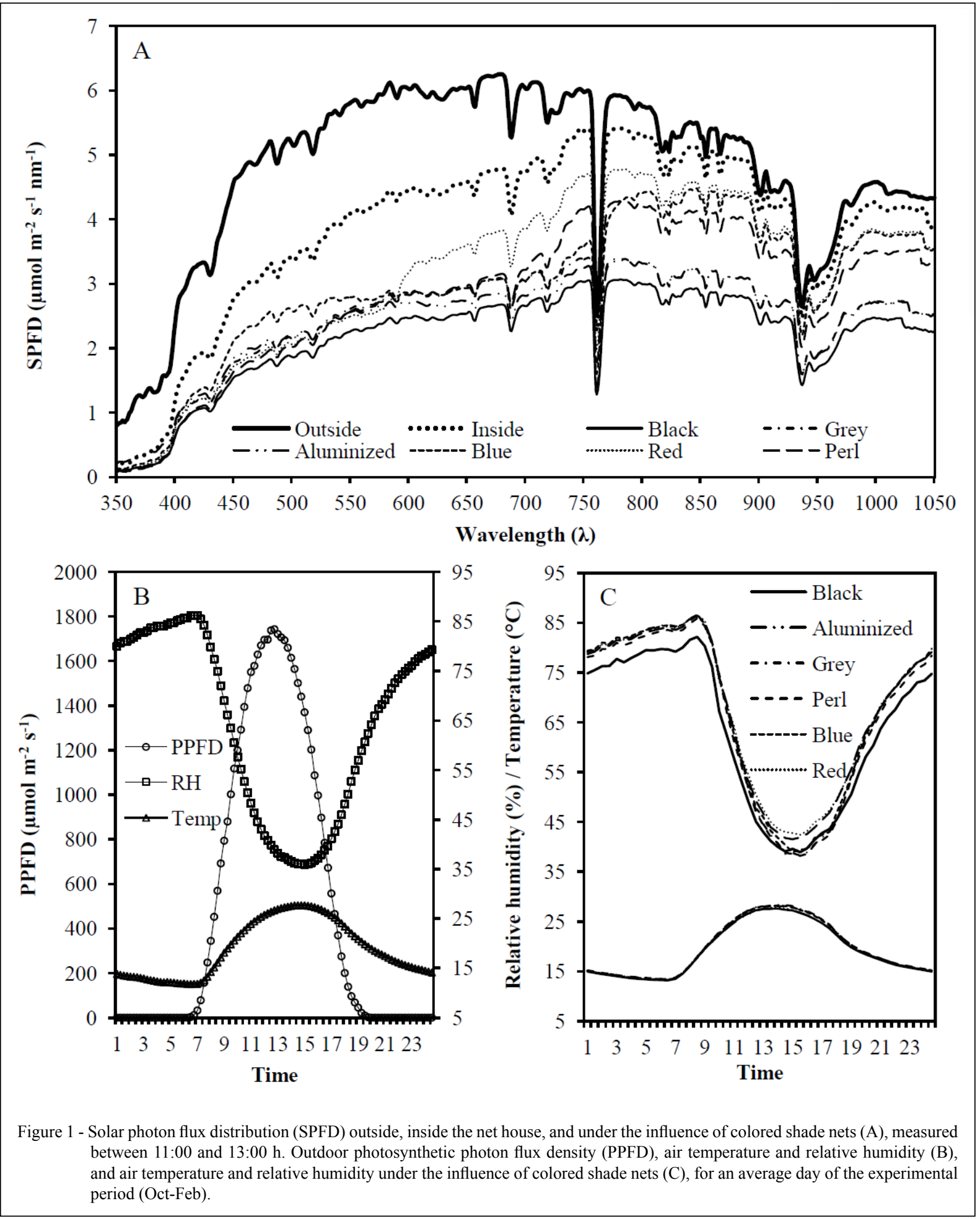

Malus domestica, Pyrus communis, Prunus persica, Diospyros kaki and Fragaria ananassa) and tomato (Solanum lycopersicum), respectively.
In general, red, pearl, blue and aluminized nets caused the main changes in gas exchange variables in cucumber plants (Table 2). Under these 
Table 1 - PPFD, blue and red light $\left(\mu \mathrm{mol} \mathrm{m} \mathrm{m}^{-2} \mathrm{~s}^{-1}\right)$ transmitted by shade nets to the 'Modan' cucumber plants. Average for the experimental period (Oct-Feb).

\begin{tabular}{lccc}
\hline & PPFD & Blue light & Red light \\
\hline Shade net & $(400-700 \mathrm{~nm})$ & $(400-500 \mathrm{~nm})$ & $(600-700 \mathrm{~nm})$ \\
Black & $615.2 \pm 4.6 \mathrm{~d}^{*}$ & $141.8 \pm 1.7 \mathrm{f}$ & $255.4 \pm 2.0 \mathrm{e}$ \\
Aluminized & $690.0 \pm 1.8 \mathrm{c}$ & $169.2 \pm 1.3 \mathrm{~b}$ & $274.9 \pm 2.3 \mathrm{~d}$ \\
Grey & $707.5 \pm 5.5 \mathrm{~b}$ & $162.3 \pm 1.6 \mathrm{c}$ & $293.7 \pm 2.1 \mathrm{c}$ \\
Perl & $695.4 \pm 3.6 \mathrm{c}$ & $150.4 \pm 1.4 \mathrm{e}$ & $298.8 \pm 2.7 \mathrm{~b}$ \\
Blue & $759.7 \pm 4.2 \mathrm{a}$ & $192.9 \pm 1.4 \mathrm{a}$ & $295.2 \pm 2.0 \mathrm{bc}$ \\
Red & $761.2 \pm 5.9 \mathrm{a}$ & $158.8 \pm 1.6 \mathrm{~d}$ & $358.4 \pm 2.6 \mathrm{a}$ \\
\hline
\end{tabular}

PPFD $=$ photosynthetic photon flux density. ${ }^{*}$ Means \pm standard error with different letters in each column are statistically different (Duncan, $\mathrm{P} \leq 0.05$ ).

nets, the cucumber leaves presented transpiration rates $(E)$ that surpassed from 6.9 to $44.8 \%$, but more consistently the first three nets, to that registered under the black net. In addition to the increase of $E$ according to the level of solar radiation transmitted by the nets, it also observed that $E$ decreased during ontogeny of cucumber plants under all nets, which agrees with MEDRANO et al. (2005).

Additionally, with red, pearl, blue and aluminized nets, stomatal conductance $(g s)$ increased from 70.8 to $125 \%$, while $\mathrm{CO}_{2}$ assimilation rates (A) also exceeded 18.4 to $37.9 \%$, compared to the values obtained with the black net. Results obtained by JANOUDI et al. (1993) in cucumber leaves that showed maximum rates from $A$ to $g s>256 \mathrm{mmol} \mathrm{m}^{-2}$ $\mathrm{s}^{-1}$, while $E$ continued increasing until $\mathrm{gs}$ of $380 \mathrm{mmol}$ $\mathrm{m}^{-2} \mathrm{~s}^{-1}$, coincided with results obtained with red, pearl, blue and aluminized nets. Those responses were promoted by greater light transmissions, not only in intensity but also in quality, referred mainly to its blue light component, with great influence on stomata development (adaxial and abaxial density, polar and equatorial diameter, etc.) (MARTINS et al., 2009) and stomatal opening (HOGEWONING et al., 2010), and

Table 2 - Responses of transpiration $(E)$, stomatal conductance $(g s)$ and $\mathrm{CO}_{2}$ assimilation $(A)$ of 'Modan' cucumber leaves to the light transmitted by the shade nets.

\begin{tabular}{|c|c|c|c|c|}
\hline Variable & Shade net & 30DAT & $60 \mathrm{DAT}$ & 90DAT \\
\hline$E$ & Black & $2.6 \pm 0.5 b^{*}$ & $2.9 \pm 0.1 \mathrm{c}$ & $2.5 \pm 0.1 \mathrm{c}$ \\
\hline \multirow[t]{5}{*}{$\left(\mathrm{mmol} \mathrm{m} \mathrm{m}^{-2} \mathrm{~s}^{-1}\right)$} & Aluminized & $4.4 \pm 0.4 \mathrm{a}$ & $3.1 \pm 0.1 \mathrm{bc}$ & $2.7 \pm 0.2 \mathrm{abc}$ \\
\hline & Grey & $3.6 \pm 0.6 \mathrm{ab}$ & $3.0 \pm 0.3 b c$ & $2.6 \pm 0.2 b c$ \\
\hline & Perl & $3.7 \pm 0.2 \mathrm{ab}$ & $3.5 \pm 0.1 \mathrm{abc}$ & $3.5 \pm 0.3 \mathrm{a}$ \\
\hline & Blue & $4.2 \pm 0.6 \mathrm{ab}$ & $4.2 \pm 0.4 \mathrm{a}$ & $3.4 \pm 0.5 \mathrm{ab}$ \\
\hline & Red & $3.0 \pm 0.6 \mathrm{ab}$ & $3.7 \pm 0.1 \mathrm{ab}$ & $3.1 \pm 0.1 \mathrm{abc}$ \\
\hline gs & Black & $241.7 \pm 69.0 b^{*}$ & $173.3 \pm 31.5 b$ & $230.0 \pm 9.3 b$ \\
\hline \multirow[t]{5}{*}{$\left(\mathrm{mmol} \mathrm{m} \mathrm{m}^{-2} \mathrm{~s}^{-1}\right)$} & Aluminized & $526.7 \pm 76.7 \mathrm{a}$ & $263.3 \pm 15.5 \mathrm{a}$ & $256.7 \pm 22.6 b$ \\
\hline & Grey & $343.3 \pm 83.3 \mathrm{ab}$ & $245.6 \pm 38.6 \mathrm{ab}$ & $221.7 \pm 14.7 b$ \\
\hline & Perl & $405.0 \pm 23.3 \mathrm{ab}$ & $325.6 \pm 8.0 \mathrm{a}$ & $293.3 \pm 29.4 \mathrm{ab}$ \\
\hline & Blue & $540.0 \pm 108.6 \mathrm{a}$ & $311.1 \pm 40.1 \mathrm{a}$ & $346.7 \pm 47.9 a$ \\
\hline & Red & $415.0 \pm 119.6 \mathrm{ab}$ & $275.6 \pm 12.5 \mathrm{a}$ & $291.7 \pm 12.5 \mathrm{ab}$ \\
\hline$A$ & Black & $10.9 \pm 0.7 \mathrm{~b}^{*}$ & $10.8 \pm 0.6 b$ & $10.3 \pm 0.5 \mathrm{~d}$ \\
\hline \multirow[t]{5}{*}{$\left(\mu \mathrm{molm}^{-2} \mathrm{~s}^{-1}\right)$} & Aluminized & $13.9 \pm 0.4 \mathrm{a}$ & $12.2 \pm 0.4 \mathrm{ab}$ & $12.2 \pm 0.3 b c$ \\
\hline & Grey & $11.6 \pm 0.5 b$ & $11.9 \pm 0.5 \mathrm{ab}$ & $11.3 \pm 0.4 \mathrm{~cd}$ \\
\hline & Perl & $14.0 \pm 0.8 \mathrm{a}$ & $13.4 \pm 1.0 \mathrm{a}$ & $13.8 \pm 0.4 \mathrm{ab}$ \\
\hline & Blue & $15.1 \pm 1.2 \mathrm{a}$ & $13.0 \pm 1.2 \mathrm{ab}$ & $14.2 \pm 1.1 \mathrm{a}$ \\
\hline & Red & $14.5 \pm 0.8 \mathrm{a}$ & $13.3 \pm 0.6 \mathrm{a}$ & $14.2 \pm 0.3 \mathrm{a}$ \\
\hline
\end{tabular}

$\mathrm{DAT}=$ days after transplant. "Means \pm standard error with different letters in each column are statistically different (Duncan, $\mathrm{P} \leq 0.05)$.

Ciência Rural, v.48, n.9, 2018. 
red light, whose energy is more efficiently absorbed by the chlorophylls and transferred to the reaction centers, thus extending energy capture that acts effectively in the photochemical reactions (LAWSON et al., 2011). Photosynthetic responses exhibited by plants under the gray net were statistically the same as those observed in the black net (Table 2). In addition, in these two nets were presented $g s<256 \mathrm{mmol} \mathrm{m}^{-2}$ $\mathrm{s}^{-1}$ that apparently limited the availability of $\mathrm{CO}_{2}$ and had repercussions on lower photosynthetic rates (JANOUDI et al., 1993; SAVVIDES et al., 2012). SHAHAK et al. (2004) observed similar responses in 'Golden Delicious' apple trees cultivated with black, gray, pearl, blue and red nets. They indicated that; although, nets reduced PAR by approximately $30 \%$, the photosynthesis rate and the stomatal conductance of exposed leaves were higher during most of the day, compared to the measurements obtained in the control plants without net and, that the highest photosynthesis rate was obtained with the red net.

Environment created by the nets significantly influenced the growth of cucumber plants. The leaf greenness, leaf area, and leaf dry weight (Table 3), increased due to the interaction of higher PPFD and red light transmitted by the red net. Due to the effects in these variables, pearl and aluminized nets were placed second, which transmitted the second largest flows of red light and blue light, respectively. These light levels favored the photosynthesis that led to increase the biomass production, which generally implies a greater area of phloem (BARZEGARGOLCHINI et al., 2017; NAZ et al., 2018) and; consequently, a more efficient transport, and greater reserve capacity of assimilates for later use in the fruit filling (MURCIA et al., 2016). Aspects that were enhanced by enrichment of the environment with diffuse light, spectrally modified by the pearl, aluminized, red and blue nets, and photosynthetically more efficient than direct light due to its greater capacity to penetrate the vegetal canopy (OREN-SHAMIR et al., 2001; ILIĆ \& FALLIK, 2017). Colored shading nets can increase light scattering by $50 \%$ or more (SHAHAK et al., 2004, 2008). Conversely, the blue net promoted high values of leaf greenness, which are usually associated with increases in PPFD and blue light transmission (COSTA et al., 2010), aspects in which it was emphasized, while plants with the lowest growth were those cultivated with black and gray nets, in each one of the variables studied.

Light environment created by plastic nets and influence of these on plant physiology affected the average fruit weight and number of fruits per plant (Table 4). With aluminized, pearl, blue and red nets, the average weight of cucumber fruits increased by between 6.9 and $8.7 \%$, due to the positive effect on the increase of plant biomass (fruits and vegetative parts) by increasing solar radiation available and efficiency photosynthetic, promoting the increase in the growth rate of individual fruits and a shorter growth period from anthesis to harvest. This, together with an increase in the number of fruits per plant, generally results in increased production (MILENKOVIĆ et al., 2012). MARCELIS et al. (2004) reported that when the plants have a larger leaf area, there is a greater source of photo-assimilates responsible for fruit growth and/or to supply a greater number of fruits, as the percentage of abortions significantly decreased in plants.

The colored nets increased the yield of cucumber, which was significantly higher with the pearl $(71 \%)$, red (48\%), aluminized and blue (46\%) nets, compared with the yield obtained with the black net $\left(52 \mathrm{t} \mathrm{ha} \mathrm{h}^{-1}\right)$, which was lower in $17 \%$ than that obtained with the gray net (Table 4); although, there were no statistical differences between them. These results agree with those observed by SHAHAK et al.

Table 3 - Influence of shade nets on growth characteristics of 'Modan' cucumber plants.

\begin{tabular}{lccc}
\hline & Leaf greenness $^{\mathrm{e}}$ & Leaf area & Leaf dry weight \\
\hline Shade net & $($ Spad units $)$ & $\left(\mathrm{dm}^{2} / \mathrm{plant}\right)$ & $(\mathrm{g} / \mathrm{plant})$ \\
Black & $41.6 \pm 1.0 \mathrm{~b}^{*}$ & $90.0 \pm 3.8 \mathrm{~b}$ & $52.5 \pm 2.2 \mathrm{~b}$ \\
Aluminized & $47.6 \pm 1.2 \mathrm{a}$ & $121.7 \pm 3.3 \mathrm{a}$ & $59.3 \pm 3.0 \mathrm{ab}$ \\
Grey & $44.2 \pm 1.3 \mathrm{~b}$ & $99.1 \pm 3.6 \mathrm{~b}$ & $54.8 \pm 2.7 \mathrm{~b}$ \\
Perl & $49.1 \pm 0.9 \mathrm{a}$ & $116.7 \pm 6.1 \mathrm{a}$ & $64.0 \pm 3.4 \mathrm{a}$ \\
Blue & $49.7 \pm 1.5 \mathrm{a}$ & $102.9 \pm 3.6 \mathrm{~b}$ & $53.3 \pm 2.5 \mathrm{~b}$ \\
Red & $51.1 \pm 1.2 \mathrm{a}$ & $125.4 \pm 5.8 \mathrm{a}$ & $57.5 \pm 4.0 \mathrm{ab}$ \\
\hline
\end{tabular}

${ }^{£}$ Average of three monthly measurements. "Means \pm standard error with different letters in each column are statistically different (Duncan, $\mathrm{P} \leq 0.05$ ). 
Table 4 - Influence of shade nets on 'Modan' cucumber fruit production.

\begin{tabular}{lccr}
\hline & Average fruit weight & Number of fruits & \multicolumn{1}{c}{ Fruits yield } \\
\hline Shade net & $(\mathrm{g} /$ fruit $)$ & $\left(\mathrm{t} \mathrm{ha}{ }^{-1}\right)$ & $51.9 \pm 4.7 \mathrm{~b}$ \\
Black & $279.0 \pm 5.7 \mathrm{~b}^{*}$ & $18.5 \pm 1.4 \mathrm{c}$ & $76.5 \pm 1.9 \mathrm{a}$ \\
Aluminized & $303.2 \pm 5.5 \mathrm{a}$ & $25.2 \pm 0.4 \mathrm{~b}$ & $60.7 \pm 4.8 \mathrm{~b}$ \\
Grey & $291.8 \pm 2.6 \mathrm{ab}$ & $20.8 \pm 1.8 \mathrm{bc}$ & $88.7 \pm 8.3 \mathrm{a}$ \\
Perl & $300.9 \pm 4.1 \mathrm{a}$ & $30.1 \pm 2.5 \mathrm{a}$ & $76.0 \pm 3.7 \mathrm{a}$ \\
Blue & $298.9 \pm 7.2 \mathrm{a}$ & $25.2 \pm 1.0 \mathrm{~b}$ & $77.1 \pm 2.2 \mathrm{a}$ \\
Red & $298.3 \pm 2.8 \mathrm{a}$ & $25.3 \pm 1.2 \mathrm{~b}$ & \\
\hline
\end{tabular}

${ }^{*}$ Means \pm standard error with different letters in each column are statistically different (Duncan, $\mathrm{P} \leq 0.05$ ).

(2008) and ILIĆ et al. (2017), who used red and pearl raschel nets with 30 to $40 \%$ of shade and obtained yields of sweet pepper of 62 to $135 \%$ higher than those obtain with the black net of the same shade level. In the same way, they agree with the results achieved by AYALA-TAFOYA et al. (2011) in tomato cultivated with black, gray, aluminized, blue, red and pearl nets, each one with 50 and $30 \%$ shade, within a greenhouse. They reported that the pearl net of 30\% of shade promoted the highest yields, total and with quality for export, and that with black and aluminized nets with $50 \%$ shade obtained lowest yields.

\section{CONCLUSION}

Colored nets altered the quality of the solar radiation that reached cucumber plants. Red and blue nets transmitted more PPFD, but red net transmitted more red light, and blue net transmitted more blue light; while black net transmitted the smaller flows of the three wavelength intervals.

In addition, with the colored nets also increased physiological activities related to the gas exchange: transpiration rate, stomatal conductance and photosynthetic $\mathrm{CO}_{2}$ assimilation rate.

The cucumber yield obtained with blue, aluminized, red or pearl net increased from 46 to $71 \%$ the yield obtained with the conventional black net. Therefore, according to the results of this investigation, any of those nets that is available, but preferably the pearl, represents an option to replace the black net and increase the yield of cucumber under net house conditions.

\section{DECLARATION OF CONFLICTING INTERESTS}

The authors declared no potential conflicts of interest with respect to the research, authorship, and/or publication of this article.

\section{ACKNOWLEDGEMENTS}

The authors thank the Universidad Autónoma de Sinaloa (UAS) and Departmento de Horticultura (DH), Protección Vegetal (DPV) and Suelos y Agua (DSA) of the Facultad de Agronomía for the facilities to accomplish this research.

\section{REFERENCES}

AL-HELAL, I.M.; ABDEL-GHANY, A.M. Responses of plastic shading nets to global and diffuse PAR transfer: Optical properties and evaluation. NJAS - Wageningen Journal of Life Sciences, vol.57, p.125-132, 2010. Available from: $<$ https://www. sciencedirect.com/science/article/pii/S1573521410000114>. Accessed: Mar. 12, 2018.doi: 10.1016/j.njas.2010.02.002.

AYALA-TAFOYA, F. et al. Growth and yield of tomato in response to sun radiation transmitted by shade nets. Terra Latinoamericana, vol.29, no.4, p.403-410, 2011.

BARZEGARGOLCHINI, B. et al. Morphological and anatomical changes in stems of Aeluropus littoralis under salt stress. Journal of Plant Molecular Breeding, vol.5, no.1, p.40-48, 2017. Available from: <http://www.jpmb-gabit.ir/article_27294_c9ddf36 2da8a85c792e333976969b16e.pdf>. Accessed: Mar. 02, 2018. doi: 10.22058/JPMB.2017.63945.1133.

BASILE, B., etal.Use of photo-selectivenets for hail protection of kiwifruit vines in southern Italy. Acta Horticulturae, vol.770, p.185-192, 2008. Available from: <https://doi.org/10.17660/ActaHortic.2008.770.21>. Accessed: Nov. 22, 2017. doi: 10.17660/ActaHortic.2008.770.21.

BASTÍAS, R.M. et al. Exploring the potential use of photo-selective nets for fruit growth regulation in apple. Chilean Journal of Agricultural Research, vol.72, no.2, p.224-231, 2012. Available from: <http://www.bioline.org.br/pdf?cj12036>. Accessed: Mar. 12, 2018. doi: $10.4067 / \mathrm{S} 0718-58392012000200010$.

BASTÍAS, R.M.; CORELLI-GRAPPADELLI, L. Light quality management in fruit orchards: physiological and technological aspects. Chilean Journal of Agricultural Research, vol.72, no.4, p.574-581, 2012. Available from: <http://www.bioline.org.br/pdf?cj12087>. Accessed: Mar. 14, 2018. doi: 10.4067/S0718-58392012000400018.

BRANT, R.S. et al. Growth, content and composition of lemon balm essential oil cultivated under color shading nets. 
Ciência Rural, vol.39, no.5, p.1401-1407, 2009. Available from: $\quad<$ http://www.scielo.br/scielo.php?script=sci_arttext\&pid $=$ S0103-84782009000500015>. Accessed: Mar. 12, 2018. doi: $10.1590 / \mathrm{S} 0103-84782009005000083$.

BUTHELEZI, M.N.D. et al. Spectral quality of photoselective nets improves phytochemicals and aroma volatiles in coriander leaves (Coriandrum sativum L.) after postharvest storage. Journal of Photochemistry and Photobiology B: Biology, Vol.161, p.328-334, 2016. Available from: <https://www.ncbi.nlm.nih.gov/ pubmed/27295414>. Accessed: Mar. 14, 2018. doi: 10.1016/j. jphotobiol.2016.05.032.

COSTA, L.C.B. et al. Effects of colored shade netting on the vegetative development and leaf structure of Ocimum selloi. Bragantia, vol.69, no.2, p.349-359, 2010. Available from: $<$ http://www.scielo.br/scielo.php?script=sci_arttext\&pid $=$ S0006-87052010000200012 $>$. Accessed: Jan. 12, 2018. doi: $10.1590 / \mathrm{S} 0006-87052010000200012$.

DÍAZ-PÉREZ, J.C. Bell pepper (Capsicum annuum L.) crop as affected by shade level microenvironment, plant growth, leaf gas exchange, and leaf mineral nutrient concentration. HortScience, vol.48, no.2, p.175-182. 2013. Available from: <http://hortsci. ashspublications.org/content/48/2/175.full>. Accessed: Mar. 13, 2018.

FALLIK, E. et al. Can colored shade nets maintain sweet pepper quality during storage and marketing? Acta Horticulturae, vol.830, p.37-44, 2009. Available from: <https:/www.actahort.org/ books/830/830_3.htm>. Accessed: Jan. 12, 2018. doi: 10.17660/ ActaHortic.2009.830.3.

FAO. Food and Agriculture Organization of the United Nations. Statistics Division. Available from: <http://faostat3.fao.org $>$. Accessed: Jan. 12, 2018.

GANELEVIN, R. World-wide commercial applications of colored shade nets technology $\left(\right.$ Chromatinet $\left.^{\mathbb{R}}\right)$. Acta Horticulturae, no.770, p.199-203, 2008. Available from: <https://www.actahort. org/books/770/770_23.htm>. Accessed: Nov. 24, 2017. doi: 10.17660/ActaHortic.2008.770.23.

GOREN, A. et al. Photoselective shade nets reduce postharvest decay development in pepper fruits. Advances in Horticultural Science, vol.25, no.1, p.26-31, 2011. Available from: <https:// www.torrossa.com/pages/ipplatform/enterTheBook.faces $>$. Accessed: Feb. 16, 2018. doi: 10.1400/172043.

GRUDA, N. Impact of environmental factors on product quality of greenhouse vegetables for fresh consumption. Critical Reviews in Plant Sciences, vol.24, no.3,p.227-247,2005. Available from: $<$ https:// www.tandfonline.com/doi/abs/10.1080/07352680591008628>. Accessed: Dec. 10, 2017. doi: 10.1080/07352680591008628.

HOGEWONING, S.W. et al. Blue light dose-responses of leaf photosynthesis, morphology, and chemical composition of Cucumis sativus grown under different combinations of red and blue light. Journal of Experimental Botany, vol.61, no.11, p.3107-3117, 2010. Available from: <https://www.ncbi.nlm.nih.gov/pmc/articles/PMC2892149/>. Accessed: Jan. 17, 2018. doi: 10.1093\%2Fjxb\%2Ferq132.

ILIĆ S. Z., et al. Effect of coloured shade-nets on plant leaf parameters and tomato fruit quality. Journal of Science Food and Agriculture, vol.95, no.13, p.2660-2667, 2015. Available from: <https://www. ncbi.nlm.nih.gov/pubmed/25389124>. Accessed: Mar. 12, 2018. doi: $10.1002 /$ jsfa. 7000
ILIĆ, Z.S., et al. Effect of shading by coloured nets on yield and fruit quality of sweet pepper. Zemdirbyste-Agriculture, vol.104, no.1, p.53-62, 2017. Available from: <http://www.zemdirbysteagriculture.1t/wp-content/uploads/2017/02/104_1_str8.pdf $>$. Accessed: Feb. 08, 2018. doi: 10.13080/z-a.2017.104.008.

ILIĆ, Z.S.; FALLIK, E. Light quality manipulation improves vegetable quality at harvest and postharvest: A review. Environmental and Experimental Botany, vol.139, p.79-90, 2017. Available from: <https://www.sciencedirect.com/science/ article/pii/S0098847217300928>. Accessed: Feb. 08, 2018. doi: 10.1016/j.envexpbot.2017.04.006.

JANOUDI, A.K. et al. Water deficits and environmental factors affect photosynthesis in leaves of cucumber (Cucumis sativus). Journal of the American Society for Horticultural Science, vol.118, no.3, p.366-370, 1993. Available from: <http://journal. ashspublications.org/content/118/3/366.full.pdf + html $>$. Accessed: Nov. 23, 2017.

KITTA, E. et al. Effects of cover optical properties on screenhouse radiative environment and sweet pepper productivity. Biosystems Engineering, vol.122, p.115-126, 2014. Available from: <https://app.dimensions.ai/details/publication/ pub.1040159330>. Accessed: Jan. 24, 2018. doi: 10.1016/j. biosystemseng.2014.04.001.

KONG, Y. et al. Pearl netting affects postharvest fruit quality in "Vergasa" sweet pepper via light environment manipulation. Scientia Horticulturae, vol.150, p.290-298, 2013. Available from: <https:// www.sciencedirect.com/science/article/pii/S0304423812005584>. Accessed: Mar. 14, 2018. doi: 10.1016/j.scienta.2012.11.029.

LAWSON, T. et al. Photosynthesis and stomatal behaviour. In: LÜTTGE, U. et al. (eds). Progress in Botany 72. SpringerVerlag. 2011. p.265-304. Available from: <https://link.springer. com/chapter/10.1007/978-3-642-13145-5_11>. Accessed: Jan. 14, 2018. doi: 10.1007/978-3-642-13145-5_11.

LEGARREA, S. et al. Comparison of UV-absorbing nets in pepper crops: spectral properties, effects on plants and pest control. Photochemistry and Photobiology, vol.86, p.324330, 2010. Available from: <https://www.ncbi.nlm.nih.gov/ pubmed/19947970 > Accessed: Mar. 16, 2018. doi: 10.1111/j.17511097.2009.00657.x.

LOBOS, G. et al. Spectral irradiance, gas exchange characteristics and leaf traits of Vaccinium corymbosum L. 'Elliot' grown under photoselective nets. Environmental and Experimental Botany, vol.75, no.1, p.142-149, 2012. Available from: <https://www. sciencedirect.com/science/article/pii/S0098847211002085>. Accessed: Mar. 15, 2018. doi: 10.1016/j.envexpbot.2011.09.006.

MARCELIS, L.F.M. et al. Flower and fruit abortion in sweet pepper in relation to source and sink strength. Journal of Experimental Botany, vol.55, no.406, p.2261-2268, 2004. Available from: $<\mathrm{https}: / /$ www.ncbi.nlm.nih.gov/pubmed/15333643>. Accessed: Nov. 23, 2017. doi: $10.1093 / \mathrm{jxb} / \mathrm{erh} 245$.

MARTÍNEZ-GUTIÉRREZ, G.A. et al. Growth and oil content of basil (Ocimum basilicum L.) grown under colored shade nets. Interciencia, vol.41, no.6, p.428-432, 2016. Available from: <http://www.redalyc. org/articulo.oa?id=33945816010>. Accessed: Mar, 12, 2018.

MARTINS, J.R. et al. Leaf anatomy of alfavaca-cravo plants cultivated under colored nets. Ciência Rural, vol.39, no.1, p.82-87, 
2009. Available from: $<$ http://www.scielo.br/scielo.php?script=sci arttext\&pid=S0103-84782009000100013>. Accessed: Nov. 23, 2017. doi: 10.1590/S0103-84782008005000040.

MASHABELA, M.N. et al. Bioactive compounds and fruit quality of green sweet pepper grown under different colored shade netting during postharvest storage. Journal of Food Science, vol.80, no.11, p.2612-2618, 2015. Available from: <https://www.ncbi. nlm.nih.gov/pubmed/26473620>. Accessed: Mar. 18, 2018. doi: 10.1111/1750-3841.13103.

MEDRANO, E. et al. Evaluation and modelling of greenhouse cucumber-crop transpiration under high and low radiation conditions. Scientia Horticulturae, vol.105, no.2, p.163-175, 2005. Available from: $<$ https://www.sciencedirect.com/science/ article/pii/S0304423805000543>. Accessed: Nov. 24, 2017. doi: 10.1016/j.scienta.2005.01.024.

MILENKOVIĆ, L. et al. Yield and pepper quality as affected by light intensity using colour shade nets. Agriculture \& Forestry, vol.58, no.1, p.19-33, 2012. Available from: <http:// www.agricultforest.ac.me/paper.php?journal_id=161\&id=2085>. Accessed: Dec. 13, 2017

MILLER, S.S. et al. Shade effects on growth, flowering and fruit of apple. Journal of Applied Horticulture, vol.17, no.2, p.101-105, 2015. Available from: $<$ http://horticultureresearch.net/journal_pdf/ Shade $\% 20$ effects $\% 20$ on $\% 20$ growth, $\% 20$ flowering\%20and $\% 20$ fruit $\% 20$ of\%20apple.pdf $>$. Accessed: Feb. 18, 2018.

MURCIA, G. et al. ABA and GA3 increase carbon allocation in different organs of grapevine plants by inducing accumulation of non-structural carbohydrates in leaves, enhancement of phloem area and expression of sugar transporters. Physiologia Plantarum, vol.156, no.3, p.323-337, 2016. Available from: <https://www. ncbi.nlm.nih.gov/pubmed/26411544>. Accessed: Mar. 02, 2018. doi: $10.1111 / \mathrm{ppl} 12390$.

NAZ, N. et al. Structural and functional aspects of salt tolerance in differently adapted ecotypes of Aeluropus lagopoides from saline desert habitats. International Journal of Agriculture and Biology, vol.20, p.41-51, 2018. Available from: $<$ https://pdfs.semanticscholar. org/a2db/a29ee327e9b7ac4362ef26551 eea8719e5c9.pdf $>$. Accessed: Mar. 07, 2018. doi: 10.17957/IJAB/15.0355.

OLIVEIRA, G. C. et al. Photosynthetic behavior, growth and essential oil production of Melissa officinalis L. cultivated under colored shade nets. Chilean Journal of Agricultural Research, vol.76, no.1, p.123-128, 2016. Available from: $<$ https://scielo.conicyt.cl/scielo.php?script=sci arttext\&pid $=$ S0718-58392016000100017 $>$. Accessed: Mar. 12, 2018. doi: $10.4067 / \mathrm{S} 0718-58392016000100017$

OMBÓDI, A. et al. Effects of external coloured shade nets on sweet peppers cultivated in walk-in plastic tunnels. Notulae Botanicae Horti Agrobotanici Cluj-Napoca, vol.43, no.2, p.398-403, 2015. Available from: <http://www.notulaebotanicae.ro/index.php/nbha/ article/view/9863>. Accessed: Mar. 12, 2018. doi: 10.15835/ nbha4329863.

OREN-SHAMIR, M. et al. Coloured shade nets can improve the yield and quality of green decorative branches of Pittosporum variegatum. The Journal of Horticultural Science \& Biotechnology, vol.76, no.3,p.353-361,2001. Available from: <https://www.tandfonline.com/ doi/abs/10.1080/14620316.2001.11511377?journalCode=thsb20>. Accessed: Nov. 24, 2017. doi: 10.1080/14620316.2001.11511377.
ORTIZ, C.J. et al. Desirable traits for cucumber plants grown under greenhouse and hydroponics at high plant densities. Revista Fitotecnia Mexicana, vol.32, no.4, p.289-294, 2009. Available from: <http://www.redalyc.org/html/610/61011789005/>. Accessed: Nov. 24, 2017.

SAVVIDES, A. et al. Co-ordination of hydraulic and stomatal conductances across light qualities in cucumber leaves. Journal of Experimental Botany, vol.63, no.3, p.1135-1143, 2012. Available from: <https://academic.oup.com/jxb/article/63/3/1135/470194>. Accessed: Nov. 12, 2017. doi: 10.1093/jxb/err348.

SANTANA, J.Q. et al. Effect of photoselective screens in the development and productivity of red and yellow sweet pepper. Acta Horticulturae, vol.956, p.493-500, 2012. Available from: $<\mathrm{https}: / /$ www.actahort.org/books/956/956_58.htm>. Accessed: Dec. 07, 2017. doi: $10.17660 /$ ActaHortic.2012.956.58.

SELAHLE, M.K.et al. Effect of photo-selective nettings on postharvest quality and bioactive compounds in selected tomato cultivars. Journal of the Science of Food and Agriculture, vol.94, no.11, p.2187-2195, 2014. Available from: <https://www. ncbi.nlm.nih.gov/pubmed/24338287>. Accessed: Mar. 14, 2018. doi: $10.1002 /$ jsfa. 6536 .

SHAHAK, Y. et al. ColorNets: crop protection and light-quality manipulation in one technology. Acta Horticulturae, no.659, p.143-151, 2004. Available from: <https://www.actahort.org/ books/659/659_17.htm>. Accessed: Nov. 24, 2017. doi: 10.17660/ ActaHortic. $200 \overline{4} .659 .17$.

SHAHAK, Y. et al. Photoselective shade netting integrated with greenhouse technologies for improved performance of vegetable and ornamental crops. Acta Horticulturae, no.797, p.75-80, 2008. Available from: <https://www.actahort.org/books/797/797 8.htm>. Accessed: Nov. 24, 2017. doi: 10.17660/ActaHortic.2008.797.8.

STATSOFT. STATISTICA (data analysis software system), version 7. Available from: <www.statsoft.com>. Accessed: Nov. 24, 2017.

TEITEL, M. The effect of screened openings on greenhouse microclimate. Agricultural and Forest Meteorology, vol.143, p.159175, 2007. Available from: <https:/www.sciencedirect.com/science/article/pii/S0168192307000305>. Accessed: Mar. 09, 2018. doi: 10.1016/j.agrformet.2007.01.005.

TINYANE, P.P. et al. Influence of photo-selective netting on fruit quality parameters and bioactive compounds in selected tomato cultivars. Scientia Horticulturae, vol.161, p.340-349, 2013 Available from: <https://www.sciencedirect.com/science/article/pii/ S0304423813003105>. Accessed: Mar. 14, 2018. doi: 10.1016/j. scienta.2013.06.024.

YANG, X. et al. Control of light environment: A key technique for highyield and high-quality vegetable production in protected farmland. Agricultural Sciences, vol.3, no.7, p.923-928, 2012. Available from: $<$ http:// www.scirp.org/journal/PaperInformation.aspx?paperID=24494>. Accessed: Dec. 12, 2017. doi: 10.4236/as.2012.37112.

ZHU, J.J. et al. Leaf gas exchange chlorophyll fluorescence, and fruit yield in hot pepper (Capsicum anmuum L.) grown under different shade and soil moisture during the fruit growth stage. Journal of Integrative Agriculture, vol.11, no. 6, p.927-937, 2012. Available from: <https://www.sciencedirect.com/science/ article/pii/S2095311912600835>. Accessed: Mar. 13, 2018. doi: 10.1016/S2095-3119(12)60083-5. 